\title{
Role of Helicobacter pylori cagA EPIYA motif and $v a c A$ genotypes for the development of gastrointestinal diseases in Southeast Asian countries: a meta-analysis
}

Shu Sahara ${ }^{1}$, Mitsushige Sugimoto $^{1 *}$, Ratha-Korn Vilaichone ${ }^{2}, V^{2}$ arocha Mahachai ${ }^{3}$, Hiroaki Miyajima ${ }^{1}$, Takahisa Furuta ${ }^{4}$ and Yoshio Yamaoka ${ }^{5}$

\begin{abstract}
Background: Infection with cagA-positive, cagA EPIYA motif ABD type, and vacA s1, m1, and i1 genotype strains of Helicobacter pylori is associated with an exacerbated inflammatory response and increased risk of gastroduodenal diseases. However, it is unclear whether the prevalence and virulence factor genotypes found in Southeast Asia are similar to those in Western countries. Here, we examined the cagA status and prevalence of cagA EPIYA motifs and vacA genotypes among $H$. pylori strains found in Southeast Asia and examined their association with gastroduodenal disease.

Methods: To determine the cagA status, cagA EPIYA motifs, and vacA genotypes of H. pylori, we conducted meta-analyses of 13 previous reports for 1,281 H. pylori strains detected from several Southeast Asian countries.

Results: The respective frequencies of cagA-positive and vacA s1, m1, and i1 genotypes among examined subjects were 93\% (1,056/1,133), 98\% (1,010/1,033), 58\% (581/1,009), and 96\% (248/259), respectively. Stratification showed significant variation in the frequencies of cagA status and vacA genotypes among countries and the individual races residing within each respective country. The frequency of the vacA m-region genotype in patients infected with East Asian-type strains differed significantly between the northern and southern areas of Vietnam $(p<0.001)$. Infection with vacA $\mathrm{m} 1$ type or cagA-positive strains was associated with an increased risk of peptic ulcer disease (odds ratio: 1.46, 95\%Cl: 1.01-2.12, $p=0.046$ and 2.83, 1.50-5.34, $p=0.001$, respectively) in the examined Southeast Asian populations.

Conclusions: Both Western- and East Asian-type strains of H. pylori are found in Southeast Asia and are predominantly cagA-positive and vacA s1 type. In Southeast Asia, patients infected with vacA m1 type or cagA-positive strains have an increased risk of peptic ulcer disease. Thus, testing for this genotype and the presence of cagA may have clinical usefulness.
\end{abstract}

Keywords: Helicobacter pylori, cagA, vacA, EPIYA, Gastric cancer, Peptic ulcer disease, Southeast Asian

\footnotetext{
* Correspondence: mitsu@hama-med.ac.jp

${ }^{1}$ First Department of Medicine, Hamamatsu University School of Medicine, Hamamatsu, Japan

Full list of author information is available at the end of the article
}

\section{Biomed Central}

(c) 2012 Sahara et al.; licensee BioMed Central Ltd. This is an Open Access article distributed under the terms of the Creative Commons Attribution License (http://creativecommons.org/licenses/by/2.0), which permits unrestricted use, distribution, and reproduction in any medium, provided the original work is properly cited. 


\section{Background}

Helicobacter pylori infection is closely associated with the development of peptic ulcer disease and gastric cancer [1-4]. H. pylori colonizes the gastric mucosa of $50 \%$ of the world's population, with infection levels exceeding $70 \%$ in developing areas, such as Latin America and Africa [5-10]. Several Southeast Asian countries also have a high prevalence of $H$. pylori infection, particularly Thailand, where the $H$. pylori infection rate ranges from $54.1 \%-76.1 \%[11,12]$. Therefore, developing countries, including those located in Southeast Asia, are considered to have a higher incidence of $H$. pylori-related diseases. However, the estimated age-standardized incidence rate of gastric cancer in Southeast Asian countries (10.2 and $4.7 / 100,000$ in men and women, respectively) is lower than those in East Asia (e.g., 124.63/100,000 in Japan and 48.25/100,000 in Korea) and South America (e.g., 33.22/100,000 in Colombia) (http://globocan.iarc.fr/). This phenomenon, which is characterized by high levels of $H$. pylori infection, but a low incidence of gastric cancer, is referred to as the "Asian paradox" $[13,14]$.

Recently, numerous studies have examined the relationships between $H$. pylori virulence factors and outer membrane proteins with gastric mucosal inflammation and gastroduodenal disease development $[9,10,15,16]$. The cag PAI including of $\operatorname{cagA}$ encodes a putative type IV secretion system, which transfers a variety of multimolecular complexes, such as CagA, and across the bacterial membrane to the extracellular space or into other attached host cells $[17,18]$. H. pylori cagA plays important roles in gastric mucosal inflammation and injury in relation to activated inflammatory cells infiltration $[19,20]$. Activated neutrophils and mononuclear cells infiltrating into gastric mucosa with $H$. pylori infection produce several pro-inflammatory cytokines (e.g., IL-1 $\beta$, IL-6, IL-8 and TNF- $\alpha$ ) and anti-inflammatory cytokines (e.g., IL-4 and IL-10). Greater than $90 \%$ of $H$. pylori strains isolated from East Asian populations carries the $\operatorname{cagA}$ gene $[7,21]$. In contrast, $40 \%$ of strains isolated in Western countries are cagA-negative [7,21]. Moreover, as tyrosine phosphorylation of CagA occurs at EPIYA sites consisting of five amino acid residues, the structure and role of the $\operatorname{cag} A$ EPIYA motif in $\operatorname{cag} A$ gene have been investigated [22-24]. The EPIYA motif exhibits genetic variation that occurs in four distinct segments, the EPIYA-A, $-\mathrm{B},-\mathrm{C}$, and -D segments [22-24]. The representative CagA of Western $H$. pylori strains possesses a single EPIYA-A and EPIYA-B segment, followed by a 34-amino-acid EPIYA-C segment (EPIYA-ABC type). The C-terminal regions of East Asian and Western CagA are characterized by the presence of EPIYA-ABD and -ABC segments, respectively [22-24]. In addition, we [7] reported that $H$. pylori strains isolated from East Asian and Western countries could be completely distinguished by polymerase chain reaction-based $\operatorname{cag} A$ 5' and 3' region genotyping, and named the East Asian type $H$. pylori strains as $\operatorname{cag} A$ 1a type and the Western type $H$. pylori strains as $\operatorname{cag} A$ 2a type. $\operatorname{CagA}$ 1a type is correspondent roughly to Western-type $\operatorname{cag} A$ (EPIYA-ABC) genotype and 2 a type to East Asian-type $\operatorname{cagA}$ (EPIYA-ABD) genotype. However, it is unclear whether the cagA EPIYA motif is associated with the development of gastrointestinal disease in Southeast Asian populations.

Gastric epithelial cell injury associated with $H$. pylori infections is caused by a vacuolating cytotoxin encoded by the $H$. pylori vacA gene. The vacA signal (s) region encodes the signal peptide and $\mathrm{N}$-terminus of processed $v a c A$ toxin. In $H$. pylori, the vacA s1 genotype is associated with fully active toxin, but type 2 genotype strains produce $v a c A$ with a short $\mathrm{N}$-terminal extension that blocks vacuole formation [25]. The vacA middle (m) region encodes part of the $55-\mathrm{KDa}$ subunit located at the C-terminus and has two genotypes ( $\mathrm{m} 1$ and $\mathrm{m} 2$ ); the former causes stronger vacuolating activities than the latter [25]. Recently, a third polymorphic determinant of vacuolating activity located between the s- and $\mathrm{m}$ - regions was identified and termed the intermediate (i) region [26]. In general, the $v a c A \mathrm{~s} 1, \mathrm{~m} 1$, and i1 genotypes of $H$. pylori are associated with an increased risk of disease due to the enhanced production of toxin with markedly higher vacuolating activity than that of $v a c A$ $\mathrm{s} 2, \mathrm{~m} 2$, and $\mathrm{i} 2$ genotype strains, which are rarely associated with peptic ulcer disease and gastric cancer [7,8,15,25,27-30]. However, it is unclear whether this association is observed in $H$. pylori strains commonly found in Southeast Asian populations.

To date, 13 studies have investigated the cagA status and genotyping of cagA EPIYA motifs and $v a c A \mathrm{~s}, \mathrm{~m}$, and i-regions in $H$. pylori strains found among Southeast Asian populations (Table 1) [7,31-42]. However, due to the small sample size in each report, it remains unclear

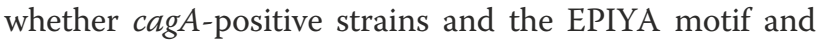
$v a c A$ genotypes are associated with an increased risk for gastrointestinal disease in Southeast Asian populations [7,31-42]. Therefore, the present study was designed to elucidate the relationship between $H$. pylori virulencefactor genotypes and $H$. pylori-related disease susceptibility in $H$. pylori-infected patients living in Southeast Asia.

\section{Methods}

\section{Study selection}

A literature search was performed using the PubMed databases for articles written in English and published before June 2011. The following search words were used: 1) $\operatorname{cagA}$ or EPIYA, 2) $v a c A$ or vacuolating cytotoxin, 3) pylori or Helicobacter, and 4) genotype. We did not include abstracts or unpublished articles. We conducted 
Table 1 Reported cagA genotypes and vacA s, $\mathrm{m}$, and i regions genotypes and cagA status in studies used in the present meta-analysis

cagA genotype

vacA genotype

\begin{tabular}{|c|c|c|c|c|c|c|c|c|c|c|c|c|c|c|c|}
\hline \multirow[b]{2}{*}{ Area/country } & \multirow[b]{2}{*}{ Authors } & \multirow[b]{2}{*}{ Year } & \multirow[b]{2}{*}{$\begin{array}{l}\text { Patients } \\
\text { (n) }\end{array}$} & \multirow[b]{2}{*}{$\operatorname{cag} A$} & & \\
\hline & & & & & $A B C$ & $\mathrm{ABCC} / \mathrm{ABCCC}$ & $A B D$ & $2 a$ & $1 a$ & $\begin{array}{c}\text { s1 } \\
(n / \%)\end{array}$ & $\begin{array}{c}s 2 \\
(\mathrm{n} / \%)\end{array}$ & $\begin{array}{c}m 1 \\
(n / \%)\end{array}$ & $\begin{array}{c}\mathrm{m} 2 \\
(\mathrm{n} / \%)\end{array}$ & $\begin{array}{c}\text { i1 } \\
\text { (n/\%) }\end{array}$ & $\begin{array}{c}\mathrm{i} 2 \\
(\mathrm{n} / \%)\end{array}$ \\
\hline Vietnam & Yamaoka Y [7] & 2002 & $25^{\mathrm{S}}$ & $24(96)$ & NA & NA & NA & $0(0)$ & $24(100)$ & $25(100)$ & $0(0)$ & $14(56)$ & $11(44)$ & NA & NA \\
\hline Vietnam & Uchida T [31] & 2009 & $103^{S}$ & 98 (95) & $4(4)$ & $0(0)$ & $94(96)$ & NA & NA & 103(100) & $1(1)$ & $44(45)$ & $54(55)$ & NA & NA \\
\hline Vietnam & Truong BX [32]] & 2009 & $22^{S}$ & $22(100)$ & $1(5)$ & $0(0)$ & $21(95)$ & NA & NA & NA & NA & NA & NA & NA & NA \\
\hline Vietnam & Nguyen TL [33] & 2010 & 100 & 95 (95) & NA & NA & NA & NA & NA & $100(100)$ & $0(0)$ & $48(48)$ & $52(52)$ & $94(94)$ & $6(6)$ \\
\hline Thailand & Yamaoka Y [7] & 2002 & $8^{5}$ & $8(100)$ & NA & NA & NA & $4(50)$ & $4(50)$ & $8(100)$ & $0(0)$ & $6(75)$ & $2(25)$ & NA & NA \\
\hline Thailand & Vilaichone RK [34] & 2004 & $98^{\mathrm{S}}$ & $98(100)$ & NA & NA & NA & $50(51)$ & $48(49)$ & $98(100)$ & $0(0)$ & $71(72)$ & $27(28)$ & NA & NA \\
\hline Thailand & Linpisarn S [35] & 2007 & 135 & $119(88)$ & NA & NA & NA & NA & NA & $132(100)$ & $0(0)$ & $73(63)$ & $42(37)$ & NA & NA \\
\hline Thailand & Chomvarin C [36] & 2008 & $112^{S}$ & $110(98)$ & NA & NA & NA & NA & NA & $112(100)$ & $0(0)$ & $65(58)$ & $47(42)$ & NA & NA \\
\hline Malaysia & Tan HJ [37] & 2005 & $127^{S}$ & $107(84)$ & NA & NA & NA & NA & NA & $117(92)$ & $10(8)$ & $81(64)$ & $46(36)$ & NA & NA \\
\hline Malaysia & Tan HJ [38] & 2006 & $73^{S}$ & $58(79)$ & NA & NA & NA & NA & NA & $65(89)$ & $8(11)$ & $46(63)$ & $27(37)$ & NA & NA \\
\hline Malaysia & Mohamed R [39] & 2009 & 93 & NA & $23(22)$ & $13(12)$ & $70(66)$ & NA & NA & NA & NA & NA & NA & NA & NA \\
\hline Malaysia & Schmidt HMA [40] & 2009 & $126^{\mathrm{S}}$ & NA & $34(28)$ & $19(16)$ & $68(56)$ & NA & NA & NA & NA & NA & NA & NA & $\overline{N A}$ \\
\hline Malaysia & Schmidt HMA [41] & 2010 & $159^{S}$ & $159(100)$ & $71(45)$ & $0(0)$ & $88(55)$ & NA & NA & $155(97)$ & $4(3)$ & $94(59)$ & $65(41)$ & $154(97)$ & $5(3)$ \\
\hline Singapore & Zheng PY [42] & 2000 & $108^{S}$ & $95(88)$ & NA & NA & NA & NA & NA & $103(99)$ & $1(1)$ & $39(38)$ & $65(62)$ & NA & NA \\
\hline
\end{tabular}

'NA' (not available) indicates a lack of data associating cagA status, EPIYA motif genotype, and vacA s-, $\mathrm{m}$-, and i-region genotypes.

The uppercase ' $s$ ' indicates the use of single colonies and the remaining studies refer to the use of gastric biopsy samples, paraffin-embedded biopsy samples, and pools of cultured colonies. 
a combined analysis to determine the prevalence of cagA-positive strains, cagA EPIYA motif genotypes, and vacA genotypes in $H$. pylori strains found in Southeast Asia and their association with gastrointestinal diseases.

\section{Inclusion Criteria}

The following criteria were applied to select published case-control studies examining the relationship between cagA EPIYA motif genotype or $v a c A$ genotype and clinical outcomes in adult populations infected with $H$. pylori isolated in four Southeast Asian countries (Vietnam, Thailand, Singapore, and Malaysia): the presence and genotypes of the $\operatorname{cagA}$ EPIYA motif (ABC, ABCC, and $\mathrm{ABD}$ genotypes) and $v a c A$ (vacA s-, m-, and i- regions) were examined by polymerase chain reaction (PCR) and original articles published in English. The references cited in these manuscripts were also screened using the same inclusion criteria. When it appeared that the same subjects were included in multiple reports, only the earliest article was selected.

\section{Data analysis}

As several studies did not measure all parameters simultaneously (cagA status and $v a c A$ s-, m-, and i-region genotypes), the patient and strain numbers (H. pylori genotype number) did not match in the following analyses.

Statistical differences in the prevalence of cagA status, EPIYA motif genotype, and $v a c A$ genotype among the individual countries and ethnic groups were determined by the chi-squared test and Fisher's exact test. The effects of cagA status, EPIYA motif genotype, and vacA genotypes on the risk of gastric cancer and peptic ulcer disease were expressed as odds ratios (ORs) with 95\% confidence intervals (CIs) with reference to non-ulcer dyspepsia (NUD) subjects infected with $H$. pylori. NUD was defined as endoscopical gastritis with no peptic ulcer disease or gastric cancer. In this study, patients with 'NUD' were regarded as the control group. All $p$ values were two-sided, and $p$ values $<0.05$ were considered statistically significant. Calculations were carried out using the statistical software StatView 5.0 (SAS Institute, Cary, NC, USA). Meta-analyses were performed using Comprehensive Meta-Analysis software (version 2, Biostat, Englewood, NJ).

\section{Results}

\section{Included studies}

Seventeen studies investigating Southeast Asian populations were identified using our search criteria (Table 1). Notably, a report from Yamaoka et al. [7] included two populations: Vietnamese and Thai. Van Doorn et al.[43] included strains isolated from Southeast Asia, but did not report the country of origin. Studies by Ho et al. [44] and Vivatvakin et al. [45] did not provide detailed $v a c A$ genotype information, and a report from Yamaoka $\mathrm{Y}$ et al. [46] investigated Vietnamese living in Houston, Texas. Finally, a total of 13 studies with a combined 1,281 patients (4 reports for Vietnam, 4 from Thailand, 5 from Malaysia, and 1 from Singapore) were included in the systematic analyses (Tables 1 and 2).

\section{Prevalence of cagA and $v a c A s, m$, and i-region genotypes} In $H$. pylori strains isolated from Southeast Asia, the respective frequencies of $v a c A \mathrm{~s} 1, \mathrm{~m} 1$, and i1 genotypes among the examined subjects were $98 \%(1,010 / 1,033)$, $58 \%(581 / 1,009)$, and $96 \%$ (248/259). The prevalence of the $v a c A$ m-region and combined $v a c A \mathrm{~s} / \mathrm{m}$ genotypes differed significantly among isolates from the various Southeast Asian countries $(p<0.001)$ (Table 2 and Figure 1). However, no significant difference between the prevalence of $v a c A$ s-region genotypes was detected. The frequency of the $v a c A \mathrm{~s} 2 \mathrm{~m} 1$ combination genotype was close to $0 \%$, which was in agreement with most previous studies examining other geographical regions $[9,25]$. Interestingly, the frequency of sub-genotypes of $v a c A \mathrm{~s} 1, \mathrm{~s} 1 \mathrm{a}$ and s1c, which are reported to be specific for East Asian H. pylori strains [7], were similar in Thailand and Malaysia (Table 2). Reports from Nguyen TL, et al. [33] and Schmidt HMA, et al. [41] investigated $v a c A$ i-region genotypes; however, the correlation with $v a c A$ i-region genotypes at the population level was unclear.

Of the 13 included studies, 93\% of $H$. pylori strains were $\operatorname{cag} A$ positive. The strains were divided into the following two groups: East Asian strains, including the EPIYA-ABD genotype [22] and 1a type according to PCR-based cagA 5' and 3' region genotyping [7], and Western-type strains, including EPIYA-ABC and -ABCC genotypes and 2a type. The prevalence of East Asianand Western-strain type cagA was $65 \%$ and $35 \%$, respectively. In the Vietnam population, 97\% (139/144) of strains was East-Asian strain type $\operatorname{cag} A$, whereas $H$. pylori strains in Thailand and Malaysia consisted of approximately half of East Asian- and Western-type strains (Table 2).

Three studies compared $H$. pylori strains isolated from the northern (Hanoi) and southern parts (Ho Chi Minh) of Vietnam [31-33] (Tables 1 and 3). Although the prevalence of the $v a c A$ s1 genotype was identical between both areas (100\%), the vacA $\mathrm{m} 1$ genotype was found at a significantly higher frequency in strains isolated from the north $(58 \% ; 60 / 104)$ than from strains detected in the south $(34 \%, 32 / 94 ; p=0.001)$. Therefore, the virulence of $H$. pylori in Vietnam may differ between the northern and southern areas of the country, despite having the same native population.

Thailand and Malaysia consist of individuals from neighboring populations. In Thailand, although the 
Table 2 Summary of cagA status, EPIYA motif genotype, and vacA s-, m- and i-region genotypes in different Southeast Asian countries

\begin{tabular}{|c|c|c|c|c|c|c|c|c|c|c|c|c|c|c|c|c|c|c|}
\hline & \multirow[b]{2}{*}{$\begin{array}{l}\text { Paper } \\
\text { (n) }\end{array}$} & \multirow[b]{2}{*}{$\begin{array}{l}\text { Patient } \\
\text { (n) }\end{array}$} & \multirow[b]{2}{*}{$\begin{array}{l}\operatorname{cag} A \\
(\mathrm{n} / \%)\end{array}$} & \multicolumn{2}{|c|}{ cagA genotype } & \multicolumn{13}{|c|}{ vacA genotype } \\
\hline & & & & $\begin{array}{l}\text { Western } \\
\text { EPIYA-ABC }\end{array}$ & $\begin{array}{l}\text { East-Asian } \\
\text { EPIYA-ABD }\end{array}$ & $\begin{array}{c}s 1 \\
(n / \%)\end{array}$ & $\begin{array}{l}\text { s1a } \\
\text { (n/\%) }\end{array}$ & $\begin{array}{c}\text { s1b } \\
\text { (n/\%) }\end{array}$ & $\begin{array}{c}\text { s1c } \\
\text { (n/\%) }\end{array}$ & $\begin{array}{c}\text { s2 } \\
(n / \%)\end{array}$ & $\begin{array}{l}m 1 \\
(n / \%)\end{array}$ & $\begin{array}{c}m 2 \\
(n / \%)\end{array}$ & $\begin{array}{l}\mathrm{s} 1 \mathrm{~m} 1 \\
(\mathrm{n} / \%)\end{array}$ & $\begin{array}{l}\text { s1m2 } \\
(\mathrm{n} / \%)\end{array}$ & $\begin{array}{l}s 2 \mathrm{~m} 1 \\
(\mathrm{n} / \%)\end{array}$ & $\begin{array}{l}\text { s2m2 } \\
(\mathrm{n} / \%)\end{array}$ & $\begin{array}{c}\mathrm{i1} \\
\text { (n/\%) }\end{array}$ & $\begin{array}{c}\text { i2 } \\
(n / \%)\end{array}$ \\
\hline Vietnam & 4 & 250 & $239(96)$ & $5(3)$ & $139(97)$ & $228(100)$ & NA & NA & NA & $1(0)$ & $106(48)$ & $117(52)$ & $106(48)$ & $117(52)$ & $0(0)$ & $0(0)$ & $94(94)$ & $6(6)$ \\
\hline Thailand & 4 & 345 & 327 (95) & $50(51)$ & $48^{*}(49)$ & $342(100)$ & 107 (62) & $0(0)$ & 66 (38) & $0(0)$ & $215^{*}(65)$ & $116(35)$ & $215^{*}(65)$ & 116 (35) & $0(0)$ & $0(0)$ & NA & NA \\
\hline Malaysia & 5 & 578 & $324(90)$ & $160(43)$ & $215^{*}(57)$ & $337(94)$ & $33(51)$ & $4(6)$ & $28(43)$ & $22(6)$ & $221^{*}(62)$ & $138(38)$ & $221 *(62)$ & $124(35)$ & $0(0)$ & $14(4)$ & $154(97)$ & $5(3)$ \\
\hline Singapore & 1 & 108 & $95(88)$ & NA & NA & $103(99)$ & NA & NA & NA & $1(1)$ & $39(38)$ & $65(63)$ & $39(38)$ & $64(62)$ & $0(0)$ & $1(1)$ & NA & NA \\
\hline Total & 13 & 1281 & $985(93)$ & $215(35)$ & $402(65)$ & $1010(98)$ & $140(59)$ & $4(2)$ & $94(39)$ & $24(2)$ & $581(58)$ & $436(42)$ & $581(58)$ & $421(42)$ & $0(0)$ & $15(1)$ & $248(96)$ & $11(4)$ \\
\hline
\end{tabular}

'NA' (not available) indicates a lack of no data associating cagA status, EPIYA motif genotype, and vacA s-, m-, and i-region genotypes. As a report from Yamaoka Y, et al. included two populations: Vietnamese and Thai [7], the number of studies was reduced by one.

*: $p<0.05$ (significant differences among different countries, when compared with Vietnam.) by use of chi-square test. 


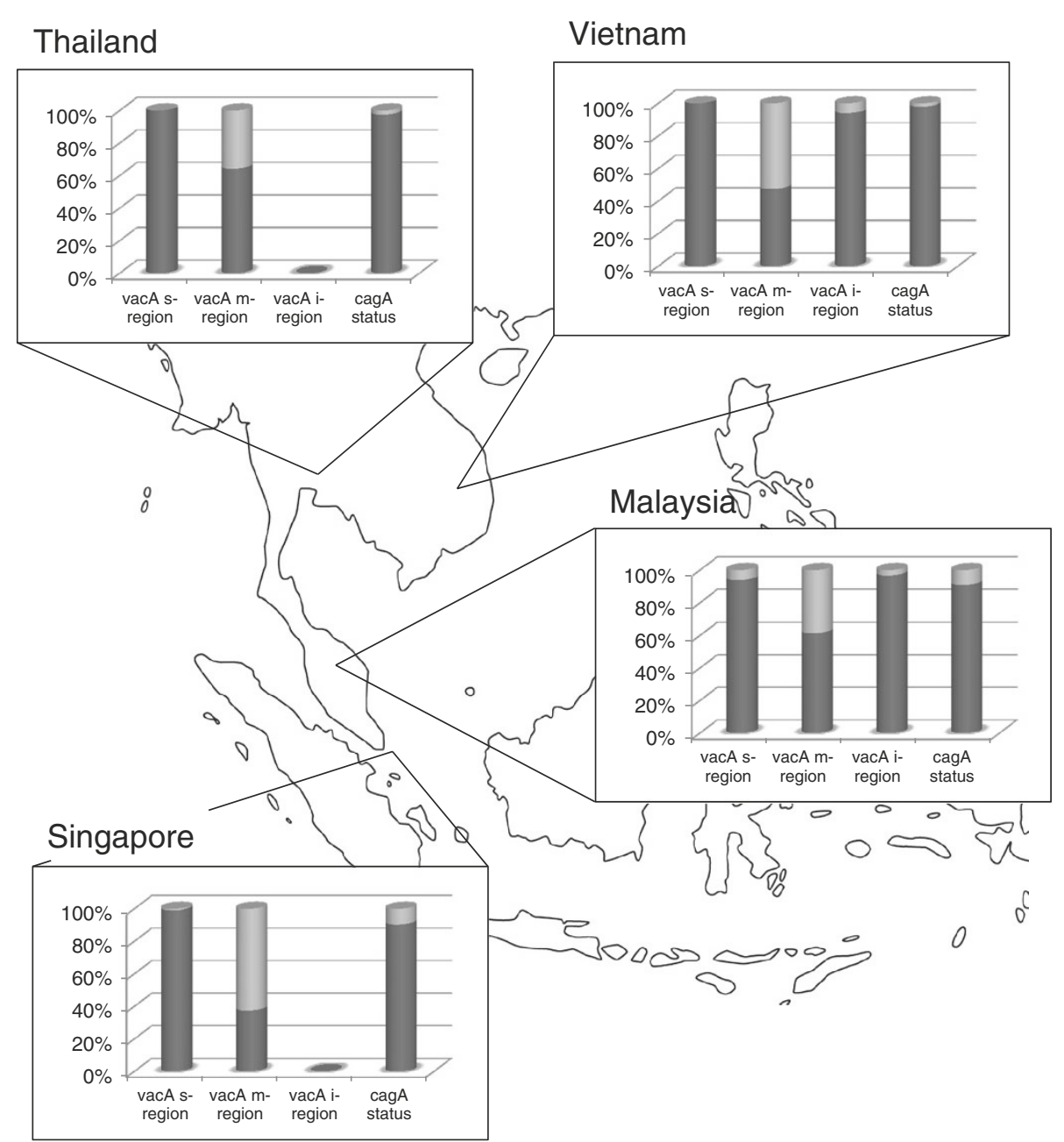

Figure 1 Proportion of vacA s, $\mathrm{m}$, and i genotypes and cagA status among $H$. pylori strains isolated from different Southeast Asia populations. The frequencies of vacA $m$ region genotype, but not vacA $s$ and i region genotypes or cagA status, significantly differed among the examined Southeast Asia countries.

prevalence of the $v a c A \mathrm{~m} 1$ genotype was higher (64\%) than that of the $\mathrm{m} 2$ genotype (36\%), vacA m-region genotypes differed among Thai, Thai-Chinese, and Chinese populations. The prevalence of the $v a c A \mathrm{~m} 1$ genotype among native Thai, who represent the majority of the population (approximately $75 \%$ ), was $92 \%$, which was significantly higher than that in Chinese $(40 \%, p<0.001)$ (Table 3). In the analysis of the $v a c A$ s1 subtype, most strains isolated from Chinese patients were the s1c subtype $(75 \%)$, which was significantly higher than that found in Thai and Thai-Chinese patients $(p<0.001)$. Moreover, the cagA EPIYA motif genotype significantly differed among the examined geographic populations $(p<0.001)$. Although East Asian-type cagA was predominant in Chinese living in Thailand, Western-type cagA was predominant in Thai patients, suggesting that most native Thai living in Thailand are infected with Western-type $H$. pylori. Therefore, this observation suggests that although
H. pylori infections in Thai are predominantly due to $v a c A$ s1m1 type strains, which have high virulence, the strains possess Western-type cagA, which is associated with weak virulence compared with East Asian strains [47].

In Malaysia, the prevalence of $v a c A \mathrm{~m} 1$ genotypes was similar among Malay (64\%), Chinese (55\%), and Indian $(70 \%)$ patients $(\mathrm{p}=0.065)$ (Table 3$)$. Most strains isolated from Indian and Malay patients were of the sla subtype ( $82 \%$ and $92 \%$, respectively). In the analysis of cagA EPIYA genotype, Chinese patients were predominantly infected with East Asian-type cagA (EPIYA-ABD), whereas Indian patients were mostly infected with Western-type cagA (EPIYA-ABC). The incidence of Western-type cagA was slightly higher in Malay patients, who formed the majority of the population. The examination of strains isolated from different ethnic groups provided an opportunity to examine the hypothesis that ethnic groups tend to retain their ancestral $H$. pylori genotype after migration $[7,46]$. 
Table 3 Differences in the distribution of cagA and vacA genotypes among different races residing within the same country

\begin{tabular}{|c|c|c|c|c|c|c|c|c|c|c|c|c|c|c|c|c|c|c|}
\hline & \multirow[b]{2}{*}{$\begin{array}{l}\text { Area/Race } \\
\text { (n) }\end{array}$} & \multirow[b]{2}{*}{$\begin{array}{l}\text { Patient } \\
\text { (n) }\end{array}$} & \multirow[b]{2}{*}{$\begin{array}{l}\operatorname{cagA} \\
(\mathrm{n} / \%)\end{array}$} & \multicolumn{2}{|c|}{ cagA genotype } & \multicolumn{13}{|c|}{ vacA genotype } \\
\hline & & & & $\begin{array}{l}\text { Western } \\
\text { EPIYA-ABC }\end{array}$ & $\begin{array}{l}\text { East-Asian } \\
\text { EPIYA-ABD }\end{array}$ & $\begin{array}{c}s 1 \\
(n / \%)\end{array}$ & $\begin{array}{l}\text { s1a } \\
(\mathrm{n} / \%)\end{array}$ & $\begin{array}{c}\text { s1b } \\
(\mathrm{n} / \%)\end{array}$ & $\begin{array}{c}\text { s1c } \\
(n / \%)\end{array}$ & $\begin{array}{c}s 2 \\
(n / \%)\end{array}$ & $\begin{array}{c}m 1 \\
(n / \%)\end{array}$ & $\begin{array}{c}m 2 \\
(n / \%)\end{array}$ & $\begin{array}{l}\text { s1m1 } \\
(\mathrm{n} / \%)\end{array}$ & $\begin{array}{l}\text { s1m2 } \\
(\mathrm{n} / \%)\end{array}$ & $\begin{array}{l}s 2 \mathrm{~m} 1 \\
(\mathrm{n} / \%)\end{array}$ & $\begin{array}{l}s 2 m 2 \\
(n / \%)\end{array}$ & $\begin{array}{c}\text { i1 } \\
\text { (n/\%) }\end{array}$ & $\begin{array}{c}\text { i2 } \\
\text { (n/\%) }\end{array}$ \\
\hline \multirow[t]{2}{*}{ Vietnam } & Hanoi (North) & 107 & $103(96)$ & $1(2)$ & $51(98)$ & $107(100)$ & NA & NA & NA & $1(1)$ & $60 *(58)$ & $44(42)$ & $60^{*}(58)$ & $44(42)$ & $0(0)$ & $0(0)$ & $50(94)$ & $3(6)$ \\
\hline & Ho Chi Minh (South) & 118 & $90(94)$ & $3(7)$ & $43(93)$ & $96(100)$ & NA & NA & NA & $0(0)$ & $32(34)$ & $62(66)$ & $32(34)$ & $62(66)$ & $0(0)$ & $0(0)$ & $44(94)$ & $3(6)$ \\
\hline \multirow[t]{3}{*}{ Thailand } & Thai & 38 & $38(100)$ & $31^{\#}(82)$ & $7(18)$ & $38(100)$ & $31(82)$ & $0(0)$ & $7^{\#}(18)$ & $0(0)$ & $35^{\#}(92)$ & $3(8)$ & $35(92)$ & $3(8)$ & $0(0)$ & $0(0)$ & NA & $\overline{N A}$ \\
\hline & Thai-Chinese & 40 & $40(100)$ & $16(42)$ & $24(60)$ & $40(100)$ & $17(43)$ & $0(0)$ & $23(58)$ & $0(0)$ & $28(70)$ & $12(30)$ & $28(70)$ & $12(30)$ & $0(0)$ & $0(0)$ & NA & NA \\
\hline & Chinese & 20 & $20(100)$ & $3(15)$ & $17(85)$ & $20(100)$ & $5(25)$ & $0(0)$ & $15(75)$ & $0(0)$ & $8(40)$ & $12(60)$ & $8(40)$ & $12(60)$ & $0(0)$ & $0(0)$ & NA & NA \\
\hline \multirow[t]{3}{*}{ Malaysia } & Chinese & 286 & $141(95)$ & $29^{* *}(13)$ & $186(87)$ & $149(100)$ & NA & NA & $\mathrm{NA}$ & $0(0)$ & $82(55)$ & $67(45)$ & $82(55)$ & $67(45)$ & $0(0)$ & $0(0)$ & $90(100)$ & $0(0)$ \\
\hline & Indian & 144 & $82(94)$ & $93(89)$ & $11(11)$ & 78 (90) & $27(82)$ & $4(12)$ & $2(6)$ & $9(10)$ & $61(70)$ & $26(30)$ & $61(70)$ & $17(20)$ & $0(0)$ & $9(10)$ & $44(90)$ & $5(10)$ \\
\hline & Malay & 75 & $43(86)$ & $25(56)$ & $19(43)$ & $45(90)$ & $23(92)$ & $0(0)$ & $2(8)$ & $5(10)$ & $32(64)$ & $18(36)$ & $32(64)$ & $13(26)$ & $0(0)$ & $5(10)$ & $22(100)$ & $0(0)$ \\
\hline
\end{tabular}

'NA' (not available) indicates a lack of data associating cagA status, EPIYA motif genotype, and vacA s-, $\mathrm{m}$-, and i-region genotypes.

*: $p<0.05$ (significant differences between Northern and Southern parts in Vietnam) by use of chi-square test, \#: $p<0.05$ (significant differences among Thai, Thai-Chinese, and Chinese in Thailand) by use of chi-square test, ${ }^{* *}: p<0.05$ (significant differences among Chinese, Indian, and Malay in Malaysia) by use of chi-square test. 
Table 4 Summary of cagA and vacA s, m, and i genotypes in relation to peptic ulcer disease and gastric cancer risk

\begin{tabular}{|c|c|c|c|c|c|c|c|c|c|c|c|c|c|c|c|c|c|c|}
\hline \multirow[b]{2}{*}{ Disease } & \multirow[b]{2}{*}{$\begin{array}{c}\text { Paper } \\
\text { (n) }\end{array}$} & \multirow[b]{2}{*}{$\begin{array}{l}\text { Patient } \\
\text { (n) }\end{array}$} & \multirow[b]{2}{*}{$\begin{array}{l}\operatorname{cagA} \\
(\mathrm{n} / \%)\end{array}$} & \multicolumn{2}{|c|}{$\operatorname{cag} A$ genotype } & \multicolumn{13}{|c|}{ vacA genotype } \\
\hline & & & & $\begin{array}{l}\text { Western } \\
\text { EPIYA-ABC }\end{array}$ & $\begin{array}{l}\text { East-Asian } \\
\text { EPIYA-ABD }\end{array}$ & $\begin{array}{c}\text { s1 } \\
\text { (n/\%) }\end{array}$ & $\begin{array}{c}\text { s1a } \\
\text { (n/\%) }\end{array}$ & $\begin{array}{l}\text { s1b } \\
\text { (n/\%) }\end{array}$ & $\begin{array}{c}\text { s1c } \\
\text { (n/\%) }\end{array}$ & $\begin{array}{c}s 2 \\
(n / \%)\end{array}$ & $\begin{array}{c}m 1 \\
(n / \%)\end{array}$ & $\begin{array}{c}m 2 \\
(n / \%)\end{array}$ & $\begin{array}{l}\text { s1m1 } \\
(\mathrm{n} / \%)\end{array}$ & $\begin{array}{l}\text { s1m2 } \\
(\mathrm{n} / \%)\end{array}$ & $\begin{array}{l}\text { s2m1 } \\
(\mathrm{n} / \%)\end{array}$ & $\begin{array}{l}\mathrm{s} 2 \mathrm{~m} 2 \\
(\mathrm{n} / \%)\end{array}$ & $\begin{array}{c}\mathrm{i1} \\
\text { (n/\%) }\end{array}$ & $\begin{array}{c}\text { i2 } \\
\text { (n/\%) }\end{array}$ \\
\hline NUD & 8 & 604 & 555 (92) & $127(44)$ & $160(56)$ & 414 (99) & $62(63)$ & $4(4)$ & $33(33)$ & $4(1)$ & $224(55)$ & $185(45)$ & $224(55)$ & $180(44)$ & $0(0)$ & $4(1)$ & $186(94)$ & $11(6)$ \\
\hline PU & 8 & 279 & $264(95)$ & $11^{*}(21)$ & $42(79)$ & $236(100)$ & $38(64)$ & $1(2)$ & $20(33)$ & $1(0)$ & 135 (59) & $92(41)$ & 134 (59) & $92(41)$ & $0(0)$ & $1(0)$ & $40(100)$ & $0(0)$ \\
\hline GC & 5 & 74 & $73(99)$ & $9^{*}(17)$ & $45(83)$ & $42(100)$ & $2(67)$ & $0(0)$ & 1 (33) & $0(0)$ & $22(54)$ & $19(46)$ & $22(54)$ & $19(46)$ & $0(0)$ & $0(0)$ & $22(100)$ & $0(0)$ \\
\hline Total & & 957 & 892 (93) & 147 (37) & 247 (63) & 692 (99) & $102(63)$ & 5 (3) & 54 (34) & $5(1)$ & $380(56)$ & 296 (44) & $380(56)$ & 291 (43) & $0(0)$ & $5(1)$ & $248(96)$ & $11(4)$ \\
\hline
\end{tabular}

*: $p<0.05$ (significantly different prevalence compared with NUD) by use of chi-square test. 


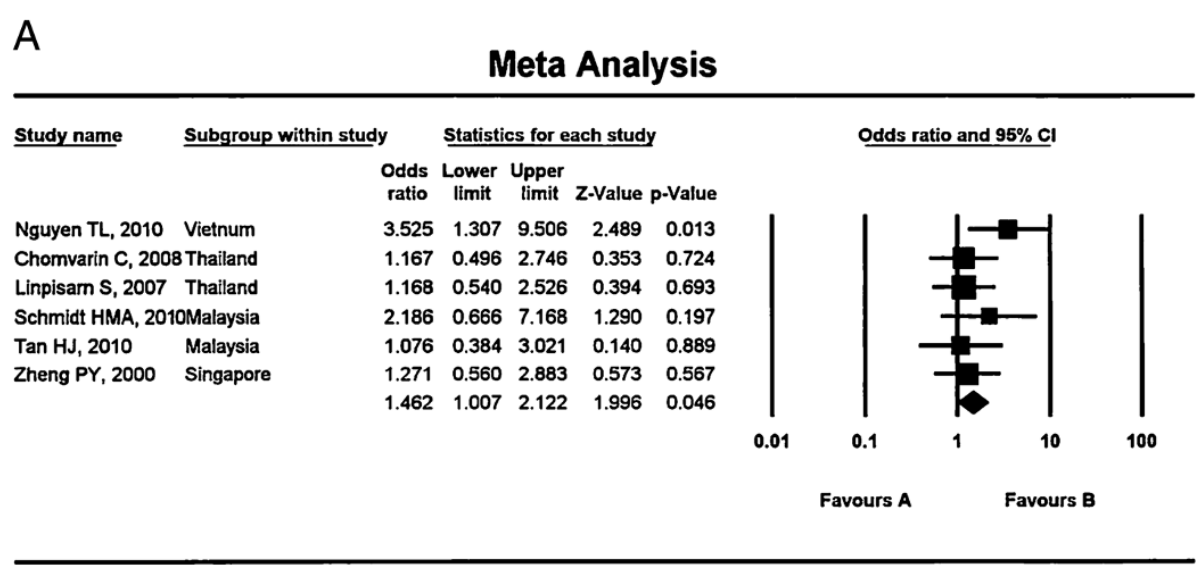

Meta Analysis

B

\section{Meta Analysis}

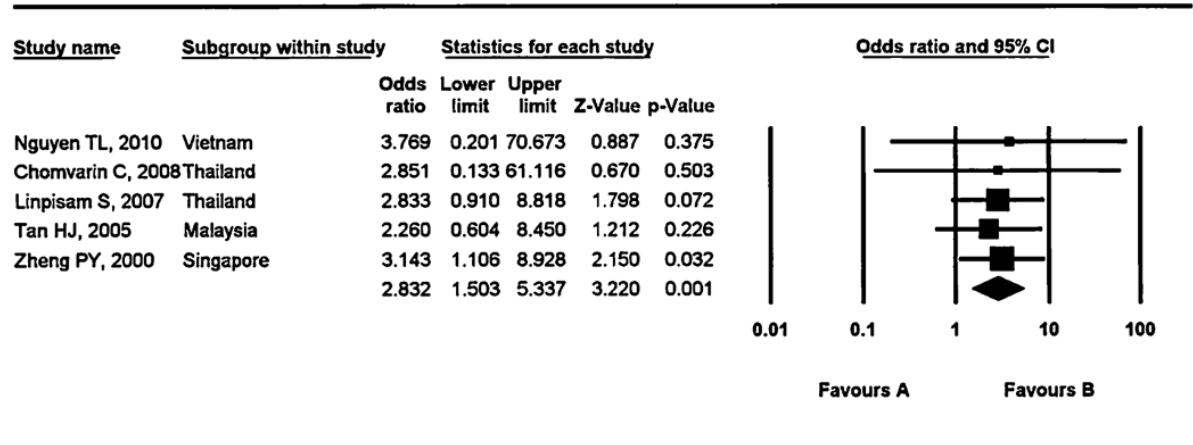

Meta Analysis

Figure 2 Results of the meta-analysis for the risk of peptic ulcer disease in infections associated with vacA $\mathrm{m} 1 \mathrm{genotype}(\mathrm{A})$ and cagA-positive (B) H. pylori strains.

Intermarriage among ethnic Thai and Chinese in Thailand also allowed examination of the transmission pathways in relation to the ethnic status of the parents. When the mother was Chinese, $84 \%$ of the offspring possessed $H$. pylori with an East Asian genotype. By contrast, when mother was Thai and father Chinese, only $29 \%$ of strains among offspring were of East Asian types. This finding is consistent with the notion that the primary caretaker of the children is the most likely source of infection. Taken together, these observations suggest that the susceptibility of different geographic populations to $H$. pylori strains and $H$. pylori-associated disease differed.

Risk of gastric cancer and peptic ulcer disease development associated with $\operatorname{cag} A$ status and $\operatorname{vac} A \mathrm{~s}, \mathrm{~m}$, and $\mathbf{i}$ genotypes

Of the 13 examined studies, 6 investigated the associations between gastroduodenal diseases and $v a c A$ s- and m-region genotypes [33,35-37,41,42], and 2 investigated disease associations based on the $v a c A$ i-region genotype $[33,41]$.
Nguyen et al. [33] reported that the frequency of vacA $\mathrm{m} 1$ alleles among H.pylori strains isolated from patients with peptic ulcer disease was $71 \%(17 / 24)$ in Vietnam, but only $41 \%$ with NUD $(31 / 76 ; p=0.146)$, although the difference was not significant. However, in combined analysis using Southeast Asian strains, the frequencies of $v a c A \mathrm{~s} 1, \mathrm{~m} 1$, and $\mathrm{i} 1$ genotypes in $H$. pylori-infected NUD were 99\%, 55\%, and 94\%, respectively, which were similar frequencies to those found in patients with peptic ulcer disease (100\%, 59\%, and 100\%, respectively) and gastric cancer $(100 \%, 54 \%$ and $100 \%$, respectively) (Table 4). In meta-analysis, infection with $v a c A \mathrm{~m} 1$ type strains increased the risk of peptic ulcer development (OR: 1.46, 95\%CI: 1.01-2.12, $p=0.046$ ) in the Southeast Asian population (Figure 2A). However, the $v a c A$ s1 and i1 genotypes were not associated with an increased risk of either peptic ulcer disease or gastric cancer.

Eight studies investigated the association between gastroduodenal disease and cagA status [32,33,35-37,41,42], while four reported the relationship between disease and $\operatorname{cag} A$ type [32,39-41]. In the meta-analysis, infection with 
cagA-positive strains increased the risk of peptic ulcer disease (OR: 2.83, 95\%CI: 1.50-5.34, $p=0.001$ ) in Southeast Asian populations. Schmidt et al. [40] reported that among Chinese patients with gastric cancer, the prevalence of EPIYA-ABD, -ABCC, and -ABC motif genotypes was $85.7 \%, 14.3 \%$, and $0 \%$, respectively. Moreover, these same authors later reported that the prevalence of the EPIYA-ABC and -ABD genotypes in Malaysia were $52.5 \%$ and $47.5 \%$ in patients with NUD, $13.6 \%$ and $86.4 \%$ with gastric cancer, and $31.3 \%$ and $68.7 \%$ with duodenal ulcer, respectively. The occurrence of East Asian-type strain (EPIYA-ABD) was higher in patients with peptic ulcer disease and gastric cancer than in those infected with Western-type strain (EPIYA-ABC) (Table 4). The prevalence of Western-type strain (EPIYA-ABC) in patients with NUD, peptic ulcer disease, and gastric cancer were 44\% (127/287), 21\% (11/ $53)$, and $17 \%(9 / 55)$, respectively, and 56\%, 79\%, and $83 \%$, respectively, for East Asian-type strain (EPIYAABD). The risk of gastric cancer and peptic ulcer disease development in patients infected with East Asian-type strain (EPIYA-ABD) was significantly increased (OR: 3.03, 95\%CI: 1.50-6.13, $p<0.002$ and OR: 3.97, 95\%CI: $1.87-8.43, p<0.001$, respectively).

\section{Discussion}

Highly virulent genotypes of $H$. pylori are associated with gastric epithelial damage, including gastric mucosal atrophy, in infected patients [30]. Notably, the vacA $\mathrm{s} 1, \mathrm{~m} 1$, and i1 genotypes and cagA-positive strains of $H$. pylori are linked to elevated inflammatory cell infiltration compared to that induced by $v a c A \mathrm{~s} 2, \mathrm{~m} 2$, and $\mathrm{i} 2$ genotypes and cagA-negative strains [48,49]. In the present study, our meta-analyses revealed a significant relationship between $H$. pylori virulence factor-associated genotypes, particularly $v a c A$ m-region genotype and cagA status, and an increased risk for the development of peptic ulcer disease in Southeast Asian populations.

An important characteristic of Southeast Asian countries is that several geographic populations live together. Recently, Breurec et al. [50] reported that five major types of historical human migration patterns have occurred in Southeast Asia: i) migration from India introducing hpEurope bacteria into Thailand, Cambodia, and Malaysia; ii) migration of the ancestors of Austro-Asiatic speaking people carrying hspEAsia bacteria into Vietnam and Cambodia; and iii) migration of the ancestors of the Thai people from Southern China into Thailand carrying H. pylori of population hpAsia2; iv) migration of Chinese to Thailand and Malaysia within the last 200 years resulting in the spread of hspEAsia strains; and v) migration of Indians to Malaysia within the last 200 years distributing both hpAsia2 and hpEurope bacteria. Therefore, both
Western and East Asian strains according to EPIYA motif genotyping can be observed in Southeast Asia. East Asian-type strain (EPIYA-ABD) was associated with an approximately three-fold increased risk of disease. Therefore, we concluded that the risk of developing $H$. pyloriassociated diseases varies among different geographic populations despite living simultaneously in the same country.

The "Asian paradox" might be explained by the widespread prevalence of weakly cytotoxic strains and correspondingly low frequency of $H$. pylori-associated diseases. However, here, the prevalence of strains with the vacA s1 region among Southeast Asia populations was similar to that of East Asian and Latin American populations, who have a higher risk of gastric carcinogenesis [7,9,10]; half of the isolated $H$. pylori strains were Western-type strains with an EPIYA-ABC genotype. The sequence of the EPIYA-D type perfectly matches the high-affinity binding sequence for SHP2 domains of SHP-2 (pY-[V/T/A/I/S]$\mathrm{X}-[\mathrm{L} / \mathrm{I} / \mathrm{V}]-\mathrm{X}-[\mathrm{F} / \mathrm{W}])$ [51,52]. In contrast, the sequences of the EPIYA-C type differ from the SHP-2 binding sequence by a single amino acid located in the $\mathrm{pY}+5$ th position [51,52]. As a result, East Asian-type CagA exhibits stronger binding activity for SHP-2 and a greater ability to induce morphological changes in epithelial cells than the Western type. The estimated age-standardized incidence rates of gastric cancer in Vietnamese patients (24.4 and 14.6/100,000 in men and women, respectively) infected with East Asian-strains of $H$. pylori are relatively higher than those in Thailand (4.2 and 3.0/100,000 in men and women, respectively) and Malaysia (10.7 and $6.4 / 100,000$ ), where the majority of the population is Thai and Malay, and are infected with Western-type strains (http://globocan.iarc.fr/). Therefore, the lower prevalence of higher virulence strains (e.g., ABD type) may explain the low frequency of gastric cancer observed in Southeast Asia, particularly in the southern part.

In Vietnam, $H$. pylori infection was detected at a rate of approximately $66 \%$ and was shown to be strongly associated with active gastritis, atrophy and intestinal metaplasia [33]. As genetic characteristics of $H$. pylori in Vietnam, the majority of isolates possess $\operatorname{cag} A$, oip $A$ "on", $v a c A$ s1, and $v a c A$ i1 genes, while the incidence of $v a c A \mathrm{~m} 1$ gene is less frequent $[7,31,33]$. Here, the prevalence of the $v a c A \mathrm{~m} 1$ genotype in patients residing in Hanoi and Ho Chi Minh were 58\% and 34\%, respectively. The prevalence of peptic ulcer disease in Hanoi, located in the northern part of Vietnam, is significantly higher than that in the southern city of Ho Chi Minh, despite similarities of ethnicity and diet [33]. Moreover, the age-standardized incidence rate of gastric cancer in Hanoi was approximately 1.5 -fold higher than that in Ho Chi Minh (27.0 vs. 18.7 cases per 100,000 males, respectively) [33]. The higher prevalence of peptic ulcer 
disease and gastric cancer observed in Hanoi might be attributable to the higher prevalence of $H$. pylori strains carrying $v a c A \mathrm{~m} 1$ in this region. Although Vietnam is located between regions with a high and low risk of gastric cancer, the rate of gastric cancer in Vietnam is approximately three times lower than that in Japan and Korea, a finding that might also explain the low prevalence of $H$. pylori strains carrying vacA $\mathrm{m} 1$ (58\% vs. nearly $100 \%$ in East Asia) $[7,16,53]$.

Thailand has a population of 60 million people and is comprised of two major ethnic groups: Thai and Chinese. Eight types of $H$. pylori strains were identified in Thailand; half of the strains possessed genotypes typically found in South Asia (cagA type 2a/cag right-end junction type III and $v a c A$ s1a-m1c), while the other half consisted of genotypes typically encountered in East Asia (cagA type 1a/cag right-end junction type II and vacA s1c-m1b) based on combinations of cagA EPIYA motif genotype, genotype at the right end of the cag pathogenicity island into five subtypes according to deletion, insertion and substitution motifs (e.g., Type II strains were predominant in China and Japan and type III strains were most common in India and type III strains were typical of strains from India) and $v a c A$ s-region genotype $[7,54]$. Thailand was considered to be a cross roads with respect to $H$. pylori genotypes, as isolates from ethnic Thai were commonly either South/Central Asian or mixed genotypes (East Asian and South/Central Asian) based on the cagA, cagPAI, and $v a c A$ genes, whereas isolates from ethnic Chinese were typically the EastAsian genotype [55]. Although the incidence of gastric cancer in Thailand is lower than that of East-Asian populations, the incidence of gastric cancer is not rare among Chinese living in Thailand, as the majority of gastric cancers $(82 \%)$ occurred among ethnic Chinese or Thai-Chinese. Therefore, the incidence of gastric cancer varies among different geographic populations, and the high prevalence of higher-virulence strains may be associated with the high frequency of gastric cancer in Chinese residing in Thailand, which is typically a lowincidence area.

In Malaysia, three distinct ethnic groups predominate: Malays, Chinese, and Indians. Chinese and Indians have migrated to Malaysia for nearly three consecutive generations. The $v a c A$ s1c genotype was also the predominant genotype detected among the Chinese patients residing in Malaysia, while s1a was predominant in Indians and Malays in Kuala Lumpur [37].

The present study has some limitations. First, in this study, because the prevalence of cagA-negative strains was very low in Southeast Asian countries, we did not demonstrate the relationship between risk of $H$. pylorirelated diseases and cagA-negative strains, which are 20$80 \%$ of $H$. pylori strains isolated from US and European population. Second, there was no information about biochemical role among different $H$. pylori virulent factors (e.g., cagA status, cagA EPIYA motif and vacA genotypes) in pathogenesis for peptic ulcer disease and gastric cancer development [56]. Recently, Mueller, et al. [56] reported association of c-Src and c-Abl kinases and phosphorylation of EPIYA motif, and differences of phosphorylation between East Asian-type strain (EPIYA$\mathrm{ABD}$ ) and Western type strain (EPIYA-ABC). Therefore, further studies will be required to clarify the role of $H$. pylori cagA EPIYA motif and vacA genotype for the development of gastrointestinal diseases.

\section{Conclusion}

We demonstrated that the prevalence of specific vacA $\mathrm{m}$-region and cagA EPIYA motif genotypes was found to vary significantly among the respective Southeast Asian countries. Moreover, our present meta-analyses identified a significant relationship between $v a c A$ m-region genotype and cagA status and the development of diseases in Southeast Asian. Importantly, most of the H. pylori strains isolated from countries with high incidences of gastric cancer concurrently possessed virulent genotypes such as $v a c A \mathrm{~s} 1 / \mathrm{m} 1$ and East Asian-type cagA [7]. In contrast, in countries with a low gastric cancer incidence, such as Thailand and Malaysia, a considerable proportion of $H$. pylori isolates exhibited less virulent genotypes, such as vacA $\mathrm{m} 2$ and Western-type cagA [7]. Based on the age-standardized incidence rate of gastric cancer, Asian countries can be categorized as either high-risk (e.g., Japan, Korea, and China), intermediate-risk (e.g., Vietnam), or low-risk (e.g., Thailand and Indonesia). The clinical usefulness of cagA EPIYA motif and vacA genotype testing must be evaluated in studies using a large number of individuals with cagA EPIYA motif and vacA genotypes.

\section{Abbreviations}

Cl: Confidence intervals; H. pylori: Helicobacter pylori; NUD: Non-ulcer dyspepsia; OR: Odds ratios; PCR: Polymerase chain reaction.

\section{Competing interests}

The authors declare no competing interests related to this study.

\section{Author contributions}

SS, MS, R-KV, VM, HM, TF, and YY designed and performed research; SS and MS analyzed data and wrote the paper. All authors read and approved the final manuscript.

\section{Disclosure}

The authors declare that there are no conflicts of interest with regard to this work.

\section{Grant support}

A grant-in-aid from the Ministry of Education, Culture, Sports, Science and Technology of Japan (23590913).

\section{Acknowledgments}

We thank Dr. Takahiro Uotani, Dr. Mihoko Yamade, Dr. Hitomi Ichikawa and Dr. Ken Sugimoto for their helpful comments. This study was supported by a 
Grant-in-Aid from the Ministry of Education, Culture, Sports, Science and Technology of Japan (23590913)

\section{Author details}

'First Department of Medicine, Hamamatsu University School of Medicine, Hamamatsu, Japan. ${ }^{2}$ Gastroenterology Unit, Department of Medicine, Thammasat University Hospital, Pathumthani, Thailand. ${ }^{3}$ Gastroenterology Unit, Department of Medicine, Chulalongkorn University Hospital, Bangkok, Thailand. ${ }^{4}$ Center for Clinical Research, Hamamatsu University School of Medicine, Hamamatsu, Japan. ${ }^{5}$ Department of Environmental and Preventive Medicine, Faculty of Medicine, Oita University, Yufu, Japan.

Received: 23 April 2012 Accepted: 17 September 2012 Published: 21 September 2012

\section{References}

1. Uemura N, Okamoto S, Yamamoto S, Matsumura N, Yamaguchi S, Yamakido M, Taniyama K, Sasaki N, Schlemper RJ: Helicobacter pylori infection and the development of gastric cancer. N Engl J Med 2001, 345(11):784-789.

2. Hopkins RJ, Girardi LS, Turney EA: Relationship between Helicobacter pylori eradication and reduced duodenal and gastric ulcer recurrence: review. Gastroenterology 1996, 110(4):1244-1252.

3. Wotherspoon AC, Doglioni C, De Boni M, Spencer J, Isaacson PG: Antibiotic treatment for low-grade gastric malt lymphoma. Lancet 1994, 343(8911):1503.

4. Fukase K, Kato M, Kikuchi S, Inoue K, Uemura N, Okamoto S, Terao S, Amagai K, Hayashi S, Asaka M: Effect of eradication of Helicobacter pylori on incidence of metachronous gastric carcinoma after endoscopic resection of early gastric cancer: an open-label, randomised controlled trial. Lancet 2008, 372(9636):392-397.

5. Perez-Perez Gl, Taylor DN, Bodhidatta L, Wongsrichanalai J, Baze WB, Dunn BE, Echeverria PD, Blaser MJ: Seroprevalence of Helicobacter pylori infections in Thailand. J Infect Dis 1990, 161(6):1237-1241.

6. Rocha GA, Queiroz DM, Mendes EN, Oliveira AM, Moura SB, Barbosa MT, Mendes CC, Lima Junior GF, Oliveira CA: Indirect immunofluorescence determination of the frequency of anti- $\mathrm{H}$ pylori antibodies in brazilian blood donors. Braz J Med Biol Res 1992, 25(7):683-689.

7. Yamaoka Y, Orito E, Mizokami M, Gutierrez O, Saitou N, Kodama T, Osato MS, Kim JG, Ramirez FC, Mahachai V, et al: Helicobacter pylori in north and south america before columbus. FEBS Lett 2002, 517(1-3):180-184.

8. Van Doorn $\amalg$, Schneeberger PM, Nouhan N, Plaisier AP, Quint WG, De Boer WA: Importance of Helicobacter pylori caga and vacA status for the efficacy of antibiotic treatment. Gut 2000, 46(3):321-326.

9. Sugimoto $M$, Yamaoka $Y$ : The association of vacA genotype and Helicobacter pylori-related disease in latin american and african populations. Clin Microbiol Infect 2009, 15(9):835-842.

10. Sugimoto M, Zali MR, Yamaoka Y: The association of vacA genotypes and Helicobacter pylori-related gastroduodenal diseases in the Middle East. Eur J Clin Microbiol Infect Dis 2009, 28(10):1227-1236.

11. Matsukura N, Yamada S, Kato S, Tomtitchong P, Tajiri T, Miki M, Matsuhisa T, Yamada N: Genetic differences in interleukin-1 beta polymorphisms among four asian populations: an analysis of the Asian paradox between $\mathrm{h}$. pylori infection and gastric cancer incidence. J Exp Clin Cancer Res 2003, 22(1):47-55.

12. Yamada S, Matsuhisa T, Makonkawkeyoon L, Chaidatch S, Kato S, Matsukura N: Helicobacter pylori infection in combination with the serum pepsinogen $\mathrm{I} / \mathrm{I}$ ratio and interleukin- 1 beta-511 polymorphisms are independent risk factors for gastric cancer in thais. J Gastroenterol 2006, 41(12):1169-1177.

13. Lunet $\mathrm{N}$, Barros H: Helicobacter pylori infection and gastric cancer: facing the enigmas. Int J Cancer 2003, 106(6):953-960.

14. Miwa H, Go MF, N S: H. pylori and gastric cancer: the Asian enigma. Am J Gastroenterol 2002, 97(5):1106-1112.

15. Yamaoka Y, Kodama T, Gutierrez O, Kim JG, Kashima K, Graham DY: Relationship between Helicobacter pylori iceA, cagA and vacA status and clinical outcome: studies in four different countries. J Clin Microbio/ 1999 37(7):2274-2279

16. Yamaoka Y, Kikuchi S, el-Zimaity HM, Gutierrez O, Osato MS, Graham DY: Importance of Helicobacter pylori oipa in clinical presentation, gastric inflammation, and mucosal interleukin 8 production. Gastroenterology 2002, 123(2):414-424
17. Covacci A, Telford JL, Del Giudice G, Parsonnet J, Rappuoli R: Helicobacter pylori virulence and genetic geography. Science 1999 284(5418):1328-1333

18. Higashi H, Tsutsumi R, Muto S, Sugiyama T, Azuma T, Asaka M, Hatakeyama M: Shp-2 tyrosine phosphatase as an intracellular target of Helicobacter pylori cagA protein. Science 2002, 295(5555):683-686

19. Broutet N, Tchamgoue S, Pereira E, Lamouliatte H, Salamon R, Megraud F: Risk factors for failure of Helicobacter pylori therapy-results of an individual data analysis of 2751 patients. Aliment Pharmacol Ther 2003, 17(1):99-109.

20. van der Hulst RW, Weel JF, Verheul SB, Keller JJ, ten Kate FJ, van der Ende A, Rauws EA, Dankert J, Tytgat GN: Treatment of Helicobacter pylori infection with low or high dose omeprazole combined with amoxycillin and the effect of early retreatment. Aliment Pharmacol Ther 1996, 10(2):165-171.

21. Yamaoka Y, El-Zimaity HM, Gutierrez O, Figura N, Kim JG, Kodama T, Kashima K, Graham DY: Relationship between the cagA 3' repeat region of Helicobacter pylori, gastric histology, and susceptibility to low $\mathrm{pH}$. Gastroenterology 1999, 117(2):342-349.

22. Higashi H, Tsutsumi R, Fujita A, Yamazaki S, Asaka M, Azuma T, Hatakeyama M: Biological activity of the Helicobacter pylori virulence factor cagA is determined by variation in the tyrosine phosphorylation sites. Proc Nat Acad Sci U S A 2002, 99(22):14428-14433.

23. Selbach M, Moese S, Hauck CR, Meyer TF, Backert S: Src is the kinase of the Helicobacter pylori caga protein in vitro and in vivo. J Biol Chem 2002, 277(9):6775-6778

24. Backert S, Moese S, Selbach M, Brinkmann V, Meyer TF: Phosphorylation of tyrosine 972 of the Helicobacter pylori cagA protein is essential for induction of a scattering phenotype in gastric epithelial cells. Mol Microbiol 2001, 42(3):631-644.

25. Atherton JC, Cao P, Peek RM Jr, Tummuru MK, Blaser MJ, Cover TL: Mosaicism in vacuolating cytotoxin alleles of Helicobacter pylori association of specific vacA types with cytotoxin production and peptic ulceration. J Biol Chem 1995, 270(30):17771-17777.

26. Rhead JL, Letley DP, Mohammadi M, Hussein N, Mohagheghi MA, Eshagh Hosseini M, Atherton JC: A new Helicobacter pylori vacuolating cytotoxin determinant, the intermediate region, is associated with gastric cancer. Gastroenterology 2007, 133(3):926-936.

27. Kidd M, Lastovica AJ, Atherton JC, Louw JA: Heterogeneity in the Helicobacter pylori vacA and cagA genes: association with gastroduodenal disease in South Africa? Gut 1999, 45(4):499-502.

28. Miehlke S, Kirsch C, Agha-Amiri K, Gunther T, Lehn N, Malfertheiner P, Stolte M, Ehninger G, Bayerdorffer E: The Helicobacter pylori vacA s1, m1 genotype and cagA is associated with gastric carcinoma in germany. Int $J$ Cancer 2000, 87(3):322-327.

29. Figueiredo C, Van Doorn $\sqcup$, Nogueira C, Soares JM, Pinho C, Figueira P Quint WG, Carneiro F: Helicobacter pylori genotypes are associated with clinical outcome in portuguese patients and show a high prevalence of infections with multiple strains. Scand J Gastroenterol 2001 36(2):128-135.

30. Atherton JC, Peek RM Jr, Tham KT, Cover TL, Blaser MJ: Clinical and pathological importance of heterogeneity in vacA, the vacuolating cytotoxin gene of Helicobacter pylori. Gastroenterology 1997, 112(1):92-99.

31. Uchida T, Nguyen LT, Takayama A, Okimoto T, Kodama M, Murakami K, Matsuhisa T, Trinh TD, Ta L, Ho DQ, et al: Analysis of virulence factors of Helicobacter pylori isolated from a vietnamese population. BMC Microbio 2009, 9:175.

32. Truong BX, Mai VT, Tanaka H, le Ly T, Thong TM, Hai HH, Van Long D, Furumatsu K, Yoshida M, Kutsumi $\mathrm{H}$, et al: Diverse characteristics of the cagA gene of Helicobacter pylori strains collected from patients from South Vietnam with gastric cancer and peptic ulcer. J Clin Microbiol 2009, 47(12):4021-4028.

33. Nguyen TL, Uchida T, Tsukamoto Y, Trinh DT, Ta L, Mai BH, Le SH, Thai KD, Ho DD, Hoang HH, et al: Helicobacter pylori infection and gastroduodenal diseases in Vietnam: a cross-sectional, hospital-based study. BMC Gastroenterol 2010, 10:114.

34. Vilaichone RK, Mahachai V, Tumwasorn S, Wu JY, Graham DY, Yamaoka Y: Molecular epidemiology and outcome of Helicobacter pylori infection in Thailand: a cultural cross roads. Helicobacter 2004, 9(5):453-459.

35. Linpisarn S, Suwan W, Lertprasertsuk N, Koosirirat C, Steger HF, Prommuangyong K, Phornphutkul K: Helicobacter pylori cagA, vacA and iceA genotypes in Northern Thai patients with gastric disease. Southeast Asian J Trop Med Public Health 2007, 38(2):356-362. 
36. Chomvarin C, Namwat W, Chaicumpar K, Mairiang P, Sangchan A, Sripa B, Tor-Udom S, Vilaichone RK: Prevalence of Helicobacter pylori vacA, cagA, cagE, iceA and baba2 genotypes in thai dyspeptic patients. Int $J$ Infect Dis 2008, 12(1):30-36.

37. Tan HJ, Rizal AM, Rosmadi MY, Goh KL: Distribution of Helicobacter pylori cagA, cagE and vacA in different ethnic groups in Kuala Lumpur, Malaysia. J Gastroenterol Hepatol 2005, 20(4):589-594.

38. Tan HJ, Rizal AM, Rosmadi MY, Goh KL: Role of Helicobacter pylori virulence factor and genotypes in non-ulcer dyspepsia. J Gastroenterol Hepatol 2006, 21(1 Pt 1):110-115.

39. Mohamed R, Hanafiah A, Rose IM, Manaf MR, Abdullah SA, Sagap I, Van Belkum A, Yaacob JA: Helicobacter pylori cagA gene variants in malaysians of different ethnicity. Eur J Clin Microbiol Infect Dis 2009, 28(7):865-869.

40. Schmidt HM, Goh KL, Fock KM, Hilmi I, Dhamodaran S, Forman D, Mitchell $\mathrm{H}$ : Distinct cagA EPIYA motifs are associated with ethnic diversity in Malaysia and Singapore. Helicobacter 2009, 14(4):256-263.

41. Schmidt HM, Andres S, Nilsson C, Kovach Z, Kaakoush NO, Engstrand L, Goh KL, Fock KM, Forman D, Mitchell H: The cagA PAl is intact and functional but $h p 0520$ varies significantly in Helicobacter pylori isolates from Malaysia and Singapore. Eur J Clin Microbiol Infect Dis 2010, 29(4):439-451.

42. Zheng PY, Hua J, Yeoh KG, Ho B: Association of peptic ulcer with increased expression of lewis antigens but not cagA, iceA, and vacA in Helicobacter pylori isolates in an Asian population. Gut 2000, 47(1):18-22.

43. Van Doorn LJ, Figueiredo C, Sanna R, Plaisier A, Schneeberger P, De Boer W, Quint W: Clinical relevance of the cagA, vacA, and iceA status of Helicobacter pylori. Gastroenterology 1998, 115(1):58-66.

44. Ho YW, Ho KY, Ascencio F, Ho B: Neither gastric topological distribution nor principle virulence genes of Helicobacter pylori contributes to clinical outcomes. World J Gastroenterol 2004, 10(22):3274-3277.

45. Vivatvakin B, Theamboonlers A, Semakachorn N, Wongsawadi L: Prevalence of cagA and vacA genotype of Helicobacter pylori in Thai children. J Med Assoc Thai 2004, 87(11):1327-1331.

46. Yamaoka Y, Malaty HM, Osato MS, Graham DY: Conservation of Helicobacter pylori genotypes in different ethnic groups in Houston, Texas. J Infect Dis 2000, 181(6):2083-2086.

47. Ogiwara H, Sugimoto M, Ohno T, Vilaichone RK, Mahachai V, Graham DY, Yamaoka Y: Role of deletion located between intermediate- and middle-region of Helicobacter pylori vacA gene in gastroduodenal diseases. J Clin Microbiol 2009, 47(11):3493-3500.

48. Nogueira C, Figueiredo C, Carneiro F, Gomes AT, Barreira R, Figueira P, Salgado C, Belo L, Peixoto A, Bravo JC, et al: Helicobacter pylori genotypes may determine gastric histopathology. Am J Pathol 2001, 158(2):647-654.

49. Martins LC, Corvelo TC, Demachki S, Araujo MT, Assumpcao MB, Vilar SC, Freitas FB, Barbosa HP, Fecury AA, do Amaral RK: Clinical and pathological importance of vacA allele heterogeneity and cagA status in peptic ulcer disease in patients from north brazil. Mem Inst Oswaldo Cruz 2005, 100(8):875-881.

50. Breurec S, Guillard B, Hem S, Brisse S, Dieye FB, Huerre M, Oung C, Raymond J, Tan TS, Thiberge JM, et al: Evolutionary history of Helicobacter pylori sequences reflect past human migrations in Southeast Asia. PLOS One 2011, 6(7):e22058.

51. Higashi H, Yokoyama K, Fujii Y, Ren S, Yuasa H, Saadat I, Murata-Kamiya N, Azuma T, Hatakeyama M: EPIYA motif is a membrane-targeting signal of Helicobacter pylori virulence factor cagA in mammalian cells. J Biol Chem 2005, 280(24):23130-23137.

52. Hatakeyama M: Oncogenic mechanisms of the Helicobacter pylori cagA protein. Nat Rev Cancer 2004, 4(9):688-694.

53. Yamaoka Y, Ojo O, Fujimoto S, Odenbreit S, Haas R, Gutierrez O, El-Zimaity HM, Reddy R, Arnqvist A, Graham DY: Helicobacter pylori outer membrane proteins and gastroduodenal disease. Gut 2006, 55(6):775-781.

54. Kersulyte D, Mukhopadhyay AK, Velapatino B, Su W, Pan Z, Garcia C, Hernandez V, Valdez Y, Mistry RS, Gilman RH, et al: Differences in genotypes of Helicobacter pylori from different human populations. J Bacteriol 2000, 182(11):3210-3218.

55. Vilaichone RK, Mahachai V, Tumwasorn S, Wu JY, Graham DY, Yamaoka Y: Gastric mucosal cytokine levels in relation to host interleukin-1 polymorphisms and Helicobacter pylori cagA genotype. Scand J Gastroenterol 2005, 40(5):530-539.
56. Mueller D, Tegtmeyer N, Brandt S, Yamaoka Y, De Poire E, Sgouras D, Wessler S, Torres J, Smolka A, Backert S: C-src and c-abl kinases control hierarchic phosphorylation and function of the cagA effector protein in Western and East Asian Helicobacter pylori strains. J Clin Invest 2012, 122(4):1553-1566.

doi:10.1186/1471-2334-12-223

Cite this article as: Sahara et al:: Role of Helicobacter pylori cagA EPIYA motif and vacA genotypes for the development of gastrointestinal diseases in Southeast Asian countries: a meta-analysis. BMC Infectious Diseases 2012 12:223.

\section{Submit your next manuscript to BioMed Central and take full advantage of:}

- Convenient online submission

- Thorough peer review

- No space constraints or color figure charges

- Immediate publication on acceptance

- Inclusion in PubMed, CAS, Scopus and Google Scholar

- Research which is freely available for redistribution

Submit your manuscript at www.biomedcentral.com/submit
C) BioMed Central 